\title{
Actively carry out mass sports activities to promote national fitness to flourish
}

\author{
Hongtao GUO \\ School of Physical Education \\ Yan'an University \\ Yan'an, 716000, China
}

\begin{abstract}
Social sports in our sport career occupies an important position for it is related to people's health enhancement, improving health and improving quality of life, it is also a part of civilization, science, healthy way of life. Paper systematically expounded an important role in the social development of sports in society, and the state of our sport in recent years in urban and rural social development, and according to the status of China's economic and social development we propose effective measures for the future.
\end{abstract}

Keywords- social sports; Fitness; health

\section{INTRODUCTION}

\section{A. The concept of social sports}

A social sport is also called "mass sports", "public sports". It is corresponds with social sports and school sports. By enterprises, institutions workers, and urban residents and farmers, to achieve fitness, heart health, fitness, entertainment, medical and other purposes which were of rich, diverse forms of physical exercise activities.

\section{B. The importance of social sports}

Social sport is as an important part of sports. "Sports development level is an important symbol of social progress and the extent of human civilization." It is related to enhancing people's health, improving health and improving quality of life. It is one of important symbols of modern civilized society, health, and science. Social sports for the future development of sport trends and the socialist spiritual civilization construction of sports undertakings have important practical significance and guide significance.

\section{TODAY'S SOCIAL SPORTS DEVELOPMENT ACHIEVEMENTS AND PROBLEMS}

\section{A. social achievements of sports development}

The gradual improvement of the social sports policy: Since the Reform and Opening, people's living standards greatly improved, the party and the state advocate social sports, providing for a solid the overall development of society and the new leap provide a solid foundation for the overall development and new improvement. In new historical period, determined physical tasks down by the fundamental law, a statutory objective of the National People must strive to achieve, for the coming years until the beginning of the next century, our fitness goals, tasks, measures put forward new requirements clearly, which is a new milestone in the history of China's sports, marking the development of sports in our society will achieve a new leap forward, it shows that the legal protection of the party and the state of implementation of the national plan making our society at this stage there had been booming sport excellent situation.

\section{B. Development of urban residents in sports activities}

Urban Sports presents a comprehensive social trend. The number of residents in regular physical activity significantly increased. The content of sports events from broadcast gymnastics, martial arts, sports-based in the past, began extend to dance, aerobics, qigong, bowling, tennis, croquet and other fashion sports. So that the majority of residents in sports have a new understanding, when experiencing the pleasure brought by sports in the combining form of fitness, recreation, pastime. Ending the simple form of the previous pursuit of fitness values, positive voluntary, amateur mainly to select interesting items, multi-organizing, paid services direction. In addition to the administrative form of organization, in the form of free association and the family in the form of community organization and business-type, quasi-business type, along with sports clubs in the social life built with the life environment.

\section{Development of rural social sports}

Rural economic developments, improvement of living standards also realize the importance of physical health and mental health of real farmers. Chinese farmer Sports Association was founded, for the masses of rural sports made a lot of contributions. In recent years, China's rural sports activities gradually embarked on the road of social and sports activities organized by the number of communities and towns greatly exceeds County Sports Commission, the basic construction of sports facilities in rural areas has made significant changes in the situation $55.71 \%$ of the counties have basketball courts, 54.5 percent of the counties have track and field, 29.86 percent of the counties have swim pool, $25.4 \%$ of the counties have the training room. County under the National Sports Associations over 131 kinds, all kinds of sports associations and co-sponsored sports, 20,645 rural villages and towns with a special (and) sports cadre 12,356, 
all kinds of counseling department, Guidance 6,424 months, and these data are still gradually growing.

\section{The main elements problem of Social Sports}

Sports population is an important indicator of social sport, which reflects the degree of participation and a sign of people pro and extent of sports, and also the degree of economic and social development. China Mass Sports Survey results report shows that in 2000, China has $35 \%$ of people participated in sports activities at least once, accounting for $33.9 \%$ of the total population, $65 \%$ of people do not participate in a physical activity, accounting for 66 of the total population $.1 \%$. By the end of 2004, all kinds of sports at all levels of society has reached 43 million people, and there are two kinds of professional and amateur groups, it shows that the low number of sports instructors, inadequate management systems. These demographics are making social sports lack of coordination, forming a barrier factor in social sports operation and development.

Economic factors social sports in our country sports census, census data, compared with the fourth national stadium area increased by 1.18 billion square meters. Site area increased by 550 million square meters per capita land area increased $0.38 \mathrm{~m}^{2}$ stadium, stadium construction funds invested per capita increase of 117.09 yuan. Sports lack investment funds. Social and political elements of sport clearly states: "the people's governments at or above the county level shall fund sports, sports infrastructure funding included in the fiscal budget and capital investment plans, and gradually increased with the economic development of sports undertakings investment. "But this did not lead to some of the city attaches great importance to building sports facilities, insufficient capital investment in certain sectors and occupation, destruction of public sports venues, facilities, and lack of appropriate behavior enforcement powers. All these show that the social sports lack of legal protection, but also illustrates the social sports legal system does not indicate problems.

\section{SOCIAL SPORTS DEVELOPMENT MEASURES}

Innovative social sports work plans. Sports departments at all levels will work as an important start point for social sports fitness work, and actively explore new ideas of social sports work with Chinese characteristics, the introduction of reforms, efforts to address the constraints of social sports development work difficulty, key issues; adhere to government-led under the premise, give full play to the role of sports associations at all levels of society, to achieve the separation of management from operation, construction of a sports executive and sports associations effective convergence and positive interaction management, operation and service mechanism; strengthening the social system construction sports theory, conduct research, summarize experience and promote the typical development of social sports planning, plans and policy measures; strengthen the guidance, and different objects take different measures for different regions, different methods work; fully mobilize the enthusiasm of youth and women and the grassroots organization and management personnel stylistic, absorbing them into the community sports teams; conditional region, fighting for the establishment of social sports community public service jobs; organization, guiding the majority of grassroots community sports, serving the people, to ensure the healthy and sustainable development of social sports work.

Establishing social sports investment guarantees mechanism work. Sports departments at all levels should be disbursed funds social sports work in the fiscal budget, funding arrangements for community sports work a certain proportion of the sports lottery in for fitness and sport grows gradually increase funding for community sports funds to work. State Sports General Administration works for the annual sports lottery fitness, they arrange no less than $10 \%$ of the funds to work as a social sport funding. In focus on ensuring training funds to finance social sports associations to carry out activities in support of underdeveloped areas and ethnic minority areas for social sports work for the Development of Social Physical fitness guide service equipped with the necessary equipment, sound, lighting, etc. to provide work, transportation subsidies. Positive and orderly development of social sports intangible assets, in the specified product, event sponsorships, and other aspects of the spokesperson explore the potential for business and social sponsorship, funding sources diversified, multichannel. Encouraging all kinds of social groups, mass organizations, enterprises and institutions to carry out organ fitness guidance services for the community sports provided material security.

Improve the social sports instructors' organizational system. Lead the formation of the sports sector, social sports instructors Association as the main broad participation of various social sports organization, the organization and the structure is reasonable, cover urban and rural areas and the service organization system in place. Chinese social sports bodies and associations further improve the working mechanism of instructors; provinces (autonomous regions and municipalities) have established social sports instructors Association, more than 70 percent of cities and more than 50 percent of the county (district) establishment of a social sports instructors Association. Each Profession Athletic Association and various sports federations to actively participate in social sports instructors work. Improve the social sports instructor management system. Establish and improve the social sports instructors work management policies, regulations, institutional system, to further improve the rating system, training system, registration system, service evaluation system and reward systems and training base assessment system, the progressive realization of social sports instructors work standardization, system and scientific.

Strengthen and improve the social sports training. Accordance with the "use-oriented, combining study with" the principle of social sports training system to improve and enhance the training of scientific, appropriateness, effectiveness; strengthen various training bases at all levels, to develop training base construction standards, good training base facilities equipped and faculty building, training base assessment examination; in accordance with the requirements of the training program, sports training at all 
levels of social norms to encourage local specialties from local realities increased training, scientific development of the annual training plan, enhance training quality inspection; broaden the training channels, encourage sports federations, Profession Athletic Association and other social organizations to participate in training; explore new approaches skills training, and actively carry out online training, production of training courses disc tissue selected experts, excellent lecture tour to the grassroots community sports coaching, through various forms of training constantly improve the levels of social sports fitness guide service.

Carry out social sports publicity. Make full use of radio, television, print media, the Internet, new media and other media way, offering social sports columns, making social sports public service ads, videos, posters, magazines and other books published by the sports and audiovisual products; promote the information technology, the establishment of China Social Sports Association website, the timely release of information and activities to improve the information service capacity, advocacy, community sport and establish a good public image, expand social impact, improve social awareness.

Promote the social construction of sports system. Developed and implemented social sports management approach, social sports work rules to follow. Establish social sports registration management system and basic statistics registration systems, the development of social sports induction requirements, service standards, ethics and codes of practice, and promote social and sports services and standardization of construction work.

Sports commended the establishment of social incentives. The implementation of the National Sports Award in recognition of outstanding social measures, the State Sports General Administration conducted every two years a national outstanding social sports award, combined with major events such as the National Sports Festival in recognition. China Sports Federation continues to organize society, "the country's most popular social sports contest" and "Social Sports Star contest." Sports departments at all levels and social sports associations to establish appropriate recognition system on the selected advanced models give spiritual and material rewards, and extensive social advocacy, social sports continue to inspire the enthusiasm and creativity of the work, making it a community of volunteer service model.

Planning organized sports community volunteer service brand activities. With the "National Fitness Day", important festivals and holidays, major events, organizational skills, physical fitness and a higher level of social sports academic theory in depth urban communities and rural towns to carry out preaching, counseling and communication activities to attract more people to participate in physical fitness activities; with the national support policies in Tibet, Xinjiang building outstanding social sports organization to Tibet, Xinjiang and fitness to carry out volunteer service activities.

Organize social sports skills display and exchange activities. Organizes regular social sports skills exhibition, show social sports style, encourage innovation, improve physical fitness guide service; the establishment of social sports channels of communication is to promote the country, positive practices of various units, learn from the advanced experience of other countries; organize regular national Social Sport observe national mass sports activities, to broaden our horizons.

\section{CONCLUSIONS}

Intelligent building system is a subsystem that contains multiple concurrent running large systems integration server responsible for handling real-time data for each subsystem. Digital design of intelligent building system functions use "platform integration, technology integration, information integration, application integration" as a guide, focusing on positioning in information resources, services and applications. Its core business locates in the information content and application services, "triple play" network and spatial database are as the basis for the core services and applications. Digital integrated intelligent systems are designed to support a variety of platforms, content-rich, informative, information and multimedia unified format, query information, browse and access dynamic interactive, vivid and intuitive, accurate information are sharing and service timely and updated quickly. System Management unified planning and unified construction, centralized management, distributed control methods, and strive to maintain, update and upgrade simple, remain easy and quick.

\section{ACKNOWLEDGEMENT}

Project Name: for the scientific research project of Yan'an University in 2014. Project number: YDQ2014-19

\section{References}

[1] Gong Yadong. Oriental Palace of effective measures for future development of social sports [J] Science and Technology Information, 2010,29: $252+281$.

[2] Lu Tao. open school gyms, sports promote the harmonious development of society [J] Science and Technology Information, 2006, S5: $138+155$.

[3] deputy director of Gansu Provincial Sports Bureau Shi Shengtai seize the opportunity to develop a whole [N]. China Sports Daily,2011-0411005 .

[4] Wang Jiang. Solid foundation strong position to promote mass sports on the steps of[N]. Zhangye Daily, 2010-04-12003.

[5] $\mathrm{Li} \mathrm{Li}$ sports public service: the development of sports demand for public financial security [J] Sports Science, 2010,06: 53-58 + 80.

[6] Bai Jianchao. Some Thoughts Perkins ultra traditional national sport and our contemporary mass sports development [J] Shandong Institute of Physical Education, 2007,03: 57-59. 